Bull. Fac .Agric., Cairo Univ. 66:288-296 (2015).

\title{
EVALUATING THE PRECISION OF FABA BEAN FIELD EXPERIMENTS
}

(Received: 19.10.2015)

\author{
By \\ Z. E. Ghareeb, H. E.A. Ibrahim and T. S. El-Marsafawy* \\ Centeral Laboratory for Design and Statistical Analyses Research, and \\ * Field Crops Research Institute, Agriculture Research Center, Giza. Egypt
}

\begin{abstract}
Two field experiments were conducted at Giza Research Station, ARC, Egypt, during 2013/14 and 2014/15 seasons. Twenty faba bean genotypes were evaluated in this study in an Alpha Lattice design with three replications for seven traits. The aim was to assess the efficiency of two experimental designs to minimizing experimental error and the coefficient of variation for yield variable, and to identify the more suitable design. Thus, data were analyzed according to alpha lattice design and randomized complete blocks design (RCBD). The results showed an improvement in the precision level thought decline in both the mean square error and the coefficient of variation. The relative efficiency (R.E.\%) of trials showed that alpha lattice design was more efficient than RCBD. The estimated average of R.E.\% indicated that the use of alpha lattice design instead of RCBD increased the experimental accuracy by $10.46,8.01,22.47,13.60,17.56$ and $55.00 \%$ for days to $50 \%$ maturity, plant height, number of branches/plant, 100-seed weight, seed yield/plant and seed yield ard/fed, respectively. Mean rank comparisons for both randomized complete block and alpha lattice design were performed. Data showed that the ranks for both designs were not constant across the experiments. Generally, the results showed that the traditional RCBD should be replaced by alpha lattice in the agricultural field trials when the number of treatments tested in an experiment is high, where a homogeneous block is quite difficult to find in field experiments. Results performed that the estimation of heritability according to alpha lattice was higher than the RCBD; therefore, the results indicated a greater efficiency for alpha design, enabling more precise estimates of genotypic variance, greater precision in the prediction of heritability in broad sense.
\end{abstract}

Key words: Faba bean, precision, alpha lattice design, relative efficiency, mean square error, coefficient of variation and heritability.

\section{INTRODUCTION}

A correct experimental design is as important as a correct statistical analysis in order to obtain valid and reliable conclusion from field experiments. Certain restrictions must be imposed when the plots are arranged in order to be able to accurately estimate the errors. The choices of experimental design as well as of statistical analysis are of major importance in field experiments. These are necessary to be correctly in order to obtain the best possible precision of the results. Randomized complete block design (RCBD) is one of the widely used designs in field trials over the entire world. Fisher (1926) emphasized the importance of randomized arrangements in the estimation of experimental error and described the randomized complete block (RCB) designs. However, in some situations, efficiency of the RCB design is not high. The problem with complete block is that the block size increases due to the increase in the number of treatments, the homogeneity of experimental plots within a large block is difficult to maintain and thus local control of experimental variability becomes inefficient (Stroup et al., 1994). It is worthy to mention that when the number of treatments is large (e.g. 20), it becomes difficult to minimize the variation with a block; thus, the experimental error increases. There are designs where the block is subdivided into incomplete blocks (sub-blocks), where each one contains only a portion of the treatments. In these designs, precision is increased because variation among the experimental units within a sub-block is minimized. These designs are called incomplete block designs.

Due to the restriction on the number of 
genotypes that may be evaluated, there have been a number of proposed lattice type designs, the most popular being the alpha designs (Giesbrecht and Gumpertz, 2004 and Hinkelman and Kempthorne, 2006). Alpha lattice design, introduced by Patterson and Williams (1976), is now routinely used for statutory field trials in the United Kingdom (Patterson and Silvey, 1980) and is also widely used for breeding and varietal trials in Australia and elsewhere. Alpha designs are resolvable incomplete block designs where the number of entries is a multiple of block size. Although these designs cannot achieve balance, they are used extensively in plant breeding primarily because they are quite flexible regarding the number of entries to be evaluated and the appropriate size of incomplete block and they allow for a good error control. In addition, these designs can be simply adapted to situations where the number of entries is not an exact multiple of block size by omitting treatments from an alpha design with a larger number of treatments.

The accuracy of this design depended on the control of heterogeneity within blocks. But unfortunately the use of RCBD is inefficient and unsuitable when the number of genotypes is as large as sixteen in a single block (Costae Silva et al., 2001 and Yang et al., 2004) because of their failure to adequately minimize the effect of soil heterogeneity (Lentner and Bishop, 1993). Also, when the number of factors and their levels increases, the number of treatment combinations increasews rapidly and it is not possible to participate all these treatment combinations in a single homogeneous block (Idrees and Khan; 2009). Many researchers (Yau, 1997; Campbell and Bauer, 2007; Masood et al., 2008; Abd ElMohsen and Abo-Hegazy, 2013 and Abd ElShafi, 2014) used alpha lattice design in field trials. They concluded that alpha lattice design is more efficient than RCBD and has potential to replace $\mathrm{RCBD}$ in regional and international trials.

The precision of RCBD relies on the control of heterogeneity within blocks. The efficiency of RCBD is criticized by the researchers in advanced countries while dealing with particularly large field experiment. Many investigators found that substantial gain in efficiency can be achieved when these experiments are used in field research comparing many varieties. Patterson and Hunter (1983) demonstrated the value of alpha lattice design in such circumstances in terms of gain in efficiency. Also, they showed that the variances of varietal yield differences from using incomplete block designs (IBD) were, on the average, 30\% lower than for completely block designs (CBD). They concluded that the lattice designs are most effective when the number of varieties is more than 50, but worthwhile reductions in variance averaging about $24 \%$ were obtained in trials with fewer than 20 varieties.

Heritability plays an important role for planning the breeding strategy (Sial, 2007). Knowledge of heritability is a basic step to identify the characters amenable to genetic improvement through selection. Malak et al., (2003) searched for characters which are associated with yield but which are more highly heritable in alpha lattice design.

The purpose of this investigation was to compare the relative efficiency of alpha lattice design relative to randomized complete blocks design for yield and yield components in some faba bean genotypes.

\section{MATERIALS AND METHODS}

A field experiment was conducted at Giza Agricultural Research Station, during two successive seasons of 2013/2014 and 2014/2015 to evaluate the yielding ability of 20 genotypes of faba bean (13 released cultivars and 7 lines). The tested genotypes originated from different hybridization in the frame of the faba bean breeding program at Legumes Research Section, Field Crops Research Institute. The details of the pedigree for the tested genotypes are presented in Table (1).

\subsection{Experimental design}

The experiment was conducted according to alpha lattice design with three replications. Each replicate contained 20 genotypes, distributed over 5 blocks, with 4 experimental units per block (Table 2). This arrangement across incomplete blocks has been found to minimize variation within the block. The randomization of 20 genotypes was done with GenStat v.14 software (Payne et al., 2011).

Each plot consisted of four ridges, with three $\mathrm{m}$ length and $60 \mathrm{~cm}$ apart with single seeded hills at one side of the ridge and $20 \mathrm{~cm}$ between hills. Seeds of all genotypes were inoculated and hand planted at density of 15 plants per a ridge. All agricultural practices of faba bean were applied.

At harvest ten guarded plants were taken at random from each experimental plot for each 
Table (1): Name and pedigree of the twenty tested faba bean genotypes.

\begin{tabular}{|c|c|c|c|c|c|}
\hline Code & $\begin{array}{l}\text { Genotype } \\
\text { name }\end{array}$ & Pedigree & Code & $\begin{array}{l}\text { Genotype } \\
\text { name }\end{array}$ & Pedigree \\
\hline G1 & Giza 3 & Cross (Giza 1 x Dutch Intr.) & G11 & $756 / 1100 / 90$ & 187/1104/80 x ILB1178 \\
\hline G2 & Giza 674 & Fam.402 x BPL582. & G12 & 952/797/93 & Rena Blanca x 461/845/83 \\
\hline G3 & Giza 843 & $561 / 2076 / 85 \times 461 / 845 / 83$ & G13 & Misr 1 & $\begin{array}{l}\text { Derived from Giza3 } \times \\
123 \mathrm{~A} / 45 / 76\end{array}$ \\
\hline G4 & Giza 461 & Cross (Giza3 x Colombia Intr.). & G14 & Nubaria 3 & Land race, Ahnasia2 \\
\hline G5 & 999/498/95 & $716 / 725 / 88$ x 900/668/89. & G15 & $X-1671$ & Giza667 × Composite16 \\
\hline G6 & Giza 716 & $461 / 843 / 83 \times 503 / 453 / 84$ & G16 & Sakha 1 & $716 / 724 / 88 \times 620 / 283 / 85$ \\
\hline G7 & Giza 717 & 503/453/83 x ILB938. & G17 & $X-1881$ & $\begin{array}{l}(\text { Giza40×Misr2) } \times \\
\text { Giza461 }\end{array}$ \\
\hline G8 & Nubaria 1 & $\begin{array}{l}\text { Single plant selection from } \\
\text { Rena Blanca. }\end{array}$ & G18 & Nubaria 2 & $\begin{array}{l}\text { X-735 (Rad.2095/76× } \\
\text { ILB1550) }\end{array}$ \\
\hline G9 & $483 / 669 / 84$ & $\begin{array}{l}\text { Individual plant selection from } \\
\text { breeding materials. }\end{array}$ & G19 & Triple white & Introduced from Sudan. \\
\hline G10 & 1001/543/84 & $716 / 725 / 88 \times 900 / 634 / 89$ & G20 & Giza 40 & $\begin{array}{l}\text { Single plant selection } \\
\text { from Rebaia } 40 .\end{array}$ \\
\hline
\end{tabular}

Table (2): Field layout of alpha lattice design with 20 genotypes in 3 complete replications. Each replicate contained 5 blocks (B) and each block contained 4 genotypes (G).

\begin{tabular}{|c|c|c|c|c|c|c|c|c|c|c|}
\hline & $\begin{array}{l}\text { B. } \\
\text { No. }\end{array}$ & G. No. & $\begin{array}{l}\text { B. } \\
\text { No. }\end{array}$ & G. No. & $\begin{array}{l}\text { B. } \\
\text { No. }\end{array}$ & G. No. & $\begin{array}{l}\text { B. } \\
\text { No. }\end{array}$ & G. No. & $\begin{array}{l}\text { B. } \\
\text { No. }\end{array}$ & G. No. \\
\hline \multirow{4}{*}{ 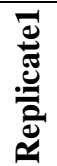 } & 1 & G1 & 2 & G3 & 3 & G5 & 4 & G13 & 5 & G9 \\
\hline & 1 & $\mathrm{G} 2$ & 2 & G18 & 3 & G7 & 4 & G20 & 5 & G11 \\
\hline & 1 & G15 & 2 & G17 & 3 & G8 & 4 & G10 & 5 & G4 \\
\hline & 1 & G12 & 2 & G14 & 3 & G19 & 4 & G16 & 5 & G6 \\
\hline \multirow{4}{*}{ 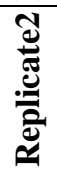 } & 1 & G11 & 2 & G7 & 3 & G18 & 4 & G13 & 5 & G10 \\
\hline & 1 & G8 & 2 & G15 & 3 & G20 & 4 & G2 & 5 & G9 \\
\hline & 1 & G12 & 2 & G17 & 3 & G5 & 4 & G4 & 5 & G14 \\
\hline & 1 & G16 & 2 & G6 & 3 & G1 & 4 & G3 & 5 & G19 \\
\hline \multirow{4}{*}{ 苞 } & 1 & G8 & 2 & G1 & 3 & G16 & 4 & $\mathrm{G} 2$ & 5 & G3 \\
\hline & 1 & G17 & 2 & G13 & 3 & G9 & 4 & G5 & 5 & G7 \\
\hline & 1 & G20 & 2 & G19 & 3 & G15 & 4 & G11 & 5 & G10 \\
\hline & 1 & G4 & 2 & G6 & 3 & G18 & 4 & G14 & 5 & G12 \\
\hline
\end{tabular}

genotype. The following data were recorded: days to $50 \%$ maturity (day), plant height $(\mathrm{cm})$, number of branches/plant, number of pods/plant, 100-seed weight (g) and seed yield/plant (g). The data of seed yield were recorded from the central harvested area $\left(7.2 \mathrm{~m}^{2}\right)$, then transformed to ardab/feddan (one ardab = $155 \mathrm{~kg}$ ).

\subsection{Statistical Methods}

Normality distributions in each trait were checked out by the Wilk Shapiro test (Neter et al., 1996). Then, data of the two seasons were statistically analyzed according to the technique of analysis of variance (ANOVA) for the alpha lattice design developed by Patterson and Williams (1976).
The linear model of observations in alpha design is as follows:

$\mathrm{y}_{\mathrm{ijk}}=\mu+\mathrm{t}_{\mathrm{i}}+\mathrm{r}_{\mathrm{j}}+\mathrm{b}_{\mathrm{jk}}+\mathrm{e}_{\mathrm{ijk}}$

where $y_{i j k}$ denotes the value of the observed trait for $\mathrm{i}$-th treatment received in the $\mathrm{k}$-th block within $\mathrm{j}$-th replicate (superblock), $t_{i}$ is the fixed effect of the $\mathrm{i}$-th treatment $(i=1,2, \ldots, t) ; r_{j}$ is the effect of the $\mathrm{j}$-th replicate (superblock) $(\mathrm{j}=$ $1,2, \ldots, r) ; b_{j k}$ is the effect of the $\mathrm{k}$-th incomplete block within the $\mathrm{j}$-th replicate $(\mathrm{k}=1,2, \ldots \mathrm{s})$ and eijk is an experimental error associated with the observation of the i-th treatment in the $\mathrm{k}$-th incomplete block within the $\mathrm{j}$-th complete replicate. 
The relative efficiency of alpha lattice design compared with a conventional RCBD was done by using the mean square error from each analysis according to the following equation: Relative efficiency\%

Error Mean Square in R.C.B.D.

$=\overline{\text { Error Mean Square in } \alpha \text {-lattice design }}$ 100

If the relative efficiency (R.E.) is less than $100 \%$ it indicates that a RCBD is a more efficient design, while value nearly equal to $100 \%$ suggests that the two designs yield similar results. Value greater than 100 suggests that alpha lattice design is more efficient than RCBD (Masood et al., 2008).

Unadjusted and adjusted genotypes means were computed and rankings compared for the randomized complete block (RCBD) and the alpha lattice design.

An estimate of $i$-th the treatment effect adjusted for block differences is

$\breve{\mathrm{T}}_{\mathrm{i}}($ adjusted $)=T_{i} /(k+1)+\left(k T_{i}-(k+1) B_{i}+G\right) /\left(k^{2}\right.$ $(k+1)), i=1, \ldots, k$

where $B_{i}$ denotes the sum of block totals of those blocks which contain treatment $\mathrm{i}, T_{i}$ is the total of yields from plots under i-th treatment and $\mathbf{G}$ is the grand total of yields. The size of each incomplete block is $\boldsymbol{k}$.

All the statistical analyses were carried out through the computer GenStat v.14 software. Heritability (broad sense) was calculated according to Singh and Chaudhary (1985), based on the following equation:

Heritability in a broad sense $\left(\mathrm{h}_{\mathrm{b}}{ }^{2}\right)=\left(\sigma_{\mathrm{g}}^{2} \mathrm{~g} / \sigma_{\mathrm{p}}^{2}\right) * 100$ $\sigma_{\mathrm{g}}^{2}=M S g-M S e / r, \sigma_{e}^{2}=M S e$ and $\sigma_{\mathrm{p}}^{2}=\sigma_{\mathrm{g}}^{2}+\sigma_{e}^{2}$ where $\sigma_{\mathrm{g}}^{2}, \sigma_{e}^{2}$ and $\sigma_{\mathrm{p}}^{2}$ are the variances due to genotypes, error and phenotypes, respectively. $M S g, M S e$ and $r$ are the mean squares of genotypes, mean squares of experimental error and number of replications, respectively.

\subsection{Analysis of variance}

3. RESULTS AND DISCUSSION

Data of the analysis of variance (ANOVA) of RCBD and Alpha Lattice design for both studied seasons are presented in Tables (3 and 4). Results in these tables revealed that the mean squares of the twenty genotypes had highly significantly differences $(p \leq 0.01)$ for all the studied traits in both seasons, except seed yield $(\operatorname{ard} / \mathrm{fed})$, which was significant only $(P \leq 0.05)$. These results indicated that considerable amount of genetic variation is present in these materials. These results are in agreement with those obtained by Zarea-Fizabady and Ghodsi (2004),
Sajjad et al. (2011), Abd El-Mohsen and AboHegazy (2013) and Abd El-Shafi (2014).

\subsection{Efficiency of RCBD and alpha lattice design}

Data of two faba bean experiments during 2013/14-2014/15 seasons are shown in Table (5). The results detected that error mean squares (Error) values of alpha lattice design were lower than error mean squares of RCBD for all the studied traits in both seasons, except the number of pods per plant in the second season. Then, the effectiveness of the alpha lattice analysis was reducing the experimental error. The coefficients of variation (C.V.\%) of Alpha Lattice design were low as compared to RCBD for all the studied traits, except the number of pods per plant in the second season. These results are in agreement with those obtained by Gleeson and Cullis (1987), Cullis and Gleeson (1991), Kempton et al. (1994), Yong-Bi Ful et al. (2000) Masood et al. (2006), Idrees and khan (2009), Abd El-Mohsen and Abo-Hegazy (2013) and Abd El-Shafi (2014).

Concerning, the value of relative efficiency (RE\%), if it is greater than $100 \%$, then the alpha lattice results in a smaller error variance and it adjusts genotypes means for block effects. In addition, if the relative efficiency is less than $100 \%$; the alpha lattice design is less efficient than the RCBD, in this case, the experiment is analyzed as RCBD and the means are not adjusted for block effects Masood et al. (2006), Idrees and khan (2009) and Abd El-Shafi (2014).

Generally, the results showed that the relative efficiencies (RE\%) were greater than $100 \%$ indicating that alpha lattice design was more efficient than randomized complete blocks design for all the studied traits except the number of pods per plant in the second season $(85.84 \%)$ which approximately equal 100 $(93.83 \%)$ in the average of both seasons. The results of relative efficiency for both seasons indicated that the use of the Alpha Lattice design instead of RCB design increased experimental precision for most yield attributes analysis. Meanwhile, the experimental precision of the first season ranged from $101.82 \%$ (the number of pods per plant) to $140.26 \%$ (seed yield ard/fed), and from $108.06 \%$ (Plant height) to $169.73 \%$ (seed yield ard/fed) in the second season.

In 2013/14 season, the value of relative efficiency percentage greater than $100 \%$ shows that alpha lattice design was more efficient than randomized complete blocks design (Table 5). 
Table (3): Mean squares of (RCBD) of the studied traits in faba bean genotypes for 2013/14 and 2014/15 seasons.

\begin{tabular}{|c|c|c|c|c|c|c|c|c|c|}
\hline S.O.V & df & Year & Mat & $\mathbf{P H}$ & Bra & Pod & HSW & SY/PI & SY/fed \\
\hline \multirow[t]{2}{*}{ Replication } & \multirow[t]{2}{*}{2} & 2014 & 6.82 & 7.77 & 0.09 & 5.42 & 335.30 & 2.10 & 0.08 \\
\hline & & 2015 & 4.87 & 59.14 & 0.26 & 2.61 & 764.70 & 9.52 & 0.53 \\
\hline \multirow[t]{2}{*}{ Genotype } & \multirow[t]{2}{*}{19} & 2014 & $113.05 * *$ & 971.01** & $4.44 * *$ & $88.49 * *$ & $871.2 * *$ & $696.71 * *$ & 11.46* \\
\hline & & 2015 & $108.30 * *$ & $1159.89 * *$ & $4.82 * *$ & $140.61 * *$ & $960.4 * *$ & $471.94 * *$ & 14.12* \\
\hline \multirow[t]{2}{*}{ Error } & \multirow[t]{2}{*}{38} & 2014 & 3.61 & 13.72 & 0.17 & 5.427 & 144.40 & 6.51 & 5.40 \\
\hline & & 2015 & 8.64 & 66.20 & 0.58 & 17.83 & 307.5 & 89.61 & 7.01 \\
\hline
\end{tabular}

$* * * *$ Significant at 1 and 5\% probability level, respectively.

Mat: days to Maturity, PH: Plant height, Bra: number of branches/plant, Pod: number of pods/plant, HSW: Hundred seed weight, SY/Pl: seed yield /plant and SY/fed: seed yield/feddan.

Table (4): Mean squares of (alpha lattice design) of the studied traits in faba bean genotypes for 2013/14 and 2014/15 seasons.

\begin{tabular}{|c|c|c|c|c|c|c|c|c|c|}
\hline S.O.V & df & Year & Mat & PH & Bra & Pod & HSW & SY/PI & SY/fed \\
\hline \multirow[t]{2}{*}{ Replication } & \multirow[t]{2}{*}{2} & 2014 & 6.817 & 7.77 & 0.09 & 5.42 & 335.3 & 2.10 & 0.08 \\
\hline & & 2015 & 4.87 & 59.14 & 0.26 & 2.61 & 764.7 & 9.52 & 0.53 \\
\hline \multirow[t]{2}{*}{ Blocks } & \multirow[t]{2}{*}{12} & 2014 & $42.47 * *$ & $354.64 * *$ & 1.01 & 36.00 & 300.1 & 178.14 & 12.96** \\
\hline & & 2015 & $27.67 * *$ & $560.00 * *$ & 2.87 & 27.24 & 465.3 & 178.39 & $17.01 * *$ \\
\hline \multirow[t]{2}{*}{ Genotypes } & \multirow[t]{2}{*}{19} & 2014 & 88.81** & 757.08** & 3.95** & 69.31** & 801.4** & 589.29** & $8.83 *$ \\
\hline & & 2015 & 97.76** & 854.78** & $3.53 * *$ & $130.63 * *$ & $900.2^{* *}$ & $438.62 * *$ & $11.77 * *$ \\
\hline \multirow[t]{2}{*}{ Error } & \multirow[t]{2}{*}{26} & 2014 & 3.38 & 12.71 & 0.14 & 5.33 & 123.6 & 5.79 & 3.85 \\
\hline & & 2015 & 7.56 & 61.26 & 0.47 & 20.77 & 278.6 & 72.98 & 4.13 \\
\hline
\end{tabular}

**** = Significant at 1 and 5\% probability level, respectively.

Mat: days to Maturity, PH: Plant height, Bra: number of branches/plant, Pod: number of pods/plant, HSW: Hundred seed

weight, SY/PI: seed yield /plant and SY/fed: seed yield/feddan.

Table (5): Estimates of error mean squares (Error), coefficient of variation (C.V.\%), relative efficiency (R.E.\%) of alpha lattice design vs RCBD, during 2013/14 and 2014/15 seasons.

\begin{tabular}{|c|c|c|c|c|c|c|c|c|c|c|c|}
\hline \multirow{3}{*}{ Trait } & \multicolumn{5}{|c|}{ Season 2013/14 } & \multicolumn{5}{|c|}{ Season 2014/15 } & \multirow{3}{*}{$\begin{array}{l}\text { Average } \\
\text { R. E. \% }\end{array}$} \\
\hline & \multicolumn{2}{|c|}{ Error } & \multicolumn{2}{|c|}{ C.V.\% } & \multirow[t]{2}{*}{ R.E.\% } & \multicolumn{2}{|c|}{ Error } & \multicolumn{2}{|c|}{ C.V.\% } & \multirow[t]{2}{*}{ R.E.\% } & \\
\hline & RCBD & Alpha & RCBD & Alpha & & RCBD & Alpha & RCBD & Alpha & & \\
\hline Mat & 3.61 & 3.38 & 1.20 & 1.16 & 106.69 & 8.64 & 7.56 & 1.80 & 1.72 & 114.23 & 110.46 \\
\hline PH & 13.72 & 12.71 & 3.40 & 3.25 & 107.95 & 66.20 & 61.26 & 7.20 & 6.92 & 108.06 & 108.01 \\
\hline Bra & 0.17 & 0.14 & 9.90 & 9.02 & 120.42 & 0.58 & 0.47 & 18.30 & 16.39 & 124.52 & 122.47 \\
\hline Pod & 5.43 & 5.33 & 12.20 & 12.12 & 101.82 & 17.83 & 20.77 & 21.40 & 23.09 & 85.84 & 93.83 \\
\hline HSW & 144.40 & 123.60 & 21.20 & 20.25 & 116.83 & 307.50 & 278.60 & 21.20 & 20.25 & $\mathbf{1 1 0 . 3 7}$ & 113.60 \\
\hline Y/PI & 6.51 & 5.80 & 5.70 & 5.36 & 112.34 & 89.61 & 72.98 & 20.40 & 18.45 & 122.79 & 117.56 \\
\hline SY/fed & 5.40 & 3.85 & 27.00 & 22.76 & 140.26 & 7.01 & 4.13 & 26.00 & 19.97 & 169.73 & 155.00 \\
\hline
\end{tabular}

Mat: days to Maturity, PH: Plant height, Bra: number of branches/plant, Pod: number of pods/plant, HSW:

Hundred seed weight, SY/PI: seed yield /plant and SY/fed: seed yield/feddan. 
Table (6): Rank changes of mean seed yield (ard/fed) values under RCBD and alpha lattice design during 2013/14 and 2014/15 seasons.

\begin{tabular}{|c|c|c|c|c|c|c|c|c|c|}
\hline \multirow{2}{*}{\multicolumn{2}{|c|}{ Genotype name }} & \multicolumn{4}{|c|}{ Season 2013/14 } & \multicolumn{4}{|c|}{$\begin{array}{r}\text { Season 2014/15 } \\
\end{array}$} \\
\hline & & \multirow{2}{*}{$\begin{array}{c}\begin{array}{c}\text { Mean } \\
\text { yield } \\
\text { (RCBD) }\end{array} \\
\mathbf{8 . 6 4}\end{array}$} & \multirow{2}{*}{$\begin{array}{c}\text { Rank } \\
11 \\
\end{array}$} & \multirow{2}{*}{$\begin{array}{c}\begin{array}{c}\text { Adjusted } \\
\text { yield } \\
\text { (Alpha) }\end{array} \\
\mathbf{8 . 5 0}\end{array}$} & \multirow{2}{*}{$\begin{array}{c}\text { Rank } \\
12 \\
\end{array}$} & \multirow{2}{*}{$\begin{array}{c}\begin{array}{c}\text { Mean } \\
\text { yield } \\
\text { (RCBD) }\end{array} \\
\mathbf{1 0 . 1 9}\end{array}$} & \multirow{2}{*}{$\begin{array}{l}\text { Ra } \\
\text { nk } \\
12 \\
\end{array}$} & \multirow{2}{*}{$\begin{array}{c}\begin{array}{c}\text { Adjusted } \\
\text { yield } \\
\text { (Alpha) }\end{array} \\
9.82\end{array}$} & \multirow{2}{*}{$\begin{array}{r}\text { Ra } \\
\text { nk }\end{array}$} \\
\hline G1 & Giza 3 & & & & & & & & \\
\hline G2 & Giza 674 & 7.13 & 6 & 8.96 & 15 & 8.88 & 7 & 10.28 & 14 \\
\hline G3 & Giza 843 & 6.40 & 3 & 6.76 & 2 & 9.15 & 8 & 9.72 & 11 \\
\hline G4 & Giza 461 & 5.97 & 2 & 6.93 & 3 & 6.38 & 1 & 7.19 & 2 \\
\hline G5 & 999/498/95 & 9.14 & 13 & 7.82 & 8 & 10.24 & 13 & 8.70 & 5 \\
\hline G6 & Giza 716 & 11.13 & 18 & 12.20 & 18 & 14.49 & 20 & 15.78 & 20 \\
\hline G7 & Giza 717 & 8.14 & 9 & 7.14 & 5 & 9.80 & 10 & 9.32 & 8 \\
\hline G8 & Nubaria 1 & 9.21 & 14 & 7.22 & 7 & 10.96 & 14 & 8.65 & 4 \\
\hline G9 & $483 / 669 / 84$ & 7.87 & 8 & 8.39 & 11 & $\mathbf{7 . 5 2}$ & 3 & 8.12 & 3 \\
\hline G10 & $1001 / 543 / 84$ & 5.71 & 1 & 7.06 & 4 & 7.25 & 2 & 9.38 & 9 \\
\hline G11 & $756 / 1100 / 90$ & 7.05 & 5 & 8.34 & 10 & 7.88 & 4 & 8.97 & 6 \\
\hline G12 & 952/797/93 & 11.89 & 20 & 12.31 & 19 & 11.45 & 15 & 11.94 & 17 \\
\hline G13 & Misr 1 & 10.88 & 16 & 13.26 & 20 & 12.37 & 17 & 14.41 & 19 \\
\hline G14 & Nubaria 3 & 7.34 & 7 & 7.19 & 6 & 8.82 & 6 & 9.02 & 7 \\
\hline G15 & X -1671 & 11.61 & 19 & 11.14 & 17 & 13.59 & 19 & 12.99 & 18 \\
\hline G16 & Sakha 1 & 8.48 & 10 & 8.80 & 14 & 9.60 & 9 & 9.44 & 10 \\
\hline G17 & $X-1881$ & 6.60 & 4 & 4.60 & 1 & 8.30 & 5 & 6.71 & 1 \\
\hline G18 & Nubaria 2 & 10.97 & 17 & 8.72 & 13 & 12.90 & 18 & 10.40 & 15 \\
\hline G19 & Triple white & 9.43 & 15 & 9.06 & 16 & 10.13 & 11 & 9.81 & 12 \\
\hline G20 & Giza 40 & 8.92 & 12 & 8.10 & 9 & 11.59 & 16 & 10.87 & 16 \\
\hline \multicolumn{2}{|c|}{ Grand mean } & 8.62 & & 8.62 & & 10.08 & & 10.08 & \\
\hline \multicolumn{2}{|c|}{ LSD } & 3.84 & & 3.23 & & 4.37 & & 3.35 & \\
\hline \multicolumn{2}{|l|}{ S.E. } & 2.32 & & 1.96 & & 2.65 & & 2.03 & \\
\hline \multicolumn{2}{|l|}{$\mathrm{h}_{\mathrm{b}}^{2} \%$} & 65.99 & & 66.22 & & 62.66 & & 71.56 & \\
\hline
\end{tabular}

Relative efficiency indicated that the use of alpha lattice design instead of RCBD increased experimental precision by $6.69,7.95,20.42$, $1.82,16.83,12.34$ and $40.26 \%$ for days to $50 \%$ maturity, plant height, number of branches/plant, number of pods/plant, 100-seed weight, seed yield/plant and seed yield ard/fed, respectively. Also, for the 2014/15 experimental trial, the precision increased by $14.23,8.06,24.52,10.37$, 22.79 and $69.73 \%$ for days to $50 \%$ maturity, plant height, number of branches/plant, 100-seed weight, seed yield/plant and seed yield ard/fed, respectively. Moreover, first season (RE\%) values were higher than the second season values for all traits except number of pods per plant and 100-seed weight. Therefore, the relative efficiency (R.E.\%) average across the two seasons confirmed that the use of alpha lattice design instead of RCBD increased experimental accuracy by 10.46, 8.01, 22.47, $13.60,17.56$ and $55.00 \%$ for days to $50 \%$ maturity, plant height, the number of branches/ plant, 100-seed weight, seed yield/plant and seed yield ard/fed, respectively.

The results indicated that there was clear benefit of using alpha lattice design. This increase in precision resulted in alpha lattice design better detected significant differences than RCBD.

\subsection{Mean comparisons of $\mathrm{RCBD}$ and alpha lattice designs}

The genotypes mean performance ranking of seed yield (ard/fed) using the two designs were estimated for both seasons (Table 6). The results showed that in both seasons the rank of genotypes according to their seed yield was extremely different under the RCBD compared with lattice design. These differences between the ranks of genotypes through both seasons may be attributed to the effect of environmental factors and their interactions with genotypes, beside the high value of experimental error mean square due to the high number of experimental plot (20 plots) included in each replicate. These 
results are in accordance with Abdelkareem and Ahmed (2003), Hager (2012), Abd El- Mohsen and Abo-Hegazy (2013) and Abd El-Shafi (2014).

Therefore, the rank orders of mean based on alpha design (least square means) and RCBD (simple means) also change, which is relevant when selecting genotypes for the purpose of recommendations for the farmers. The effect is illustrated in Table (6) for season 1, where all genotypes revealed significant rank changes except seven (G1, G3, G4, G6, G12, G14 and G19 genotypes), when ordering 20 genotypes according to their yield performance. Meanwhile, the mean ranks significant differences in season 2 were detected in the all genotypes except (G1, G4, G6, G9, G14, G15, G16, G19 and G20 genotypes).

Similarly, several shuffling in ranks of different varieties have been observed for season 1 and 2 (Table 6), e.g. genotype number 1 (Giza 3) gave a rank of seed yield ard/fed at number 11 and 12 (8.64 and $10.19 \mathrm{ard} /$ fed), respectively, under RCBD moved up and attained a higher rank place of 12 and 13 (8.50 and $9.82 \mathrm{ard} / \mathrm{fed}$ ), respectively, under alpha lattice with an reduction adjustment of 0.14 and $0.37 \mathrm{ard} / \mathrm{fed}$, respectively. While genotype number 2 (Giza 674) moved from rank number 6 and 7 (7.13 and $8.88 \mathrm{ard} / \mathrm{fed}$ ), respectively, under RCBD to rank number 15 and 14 (8.96 and 10.28 ard/fed), respectively under alpha lattice with an upward adjustment of 1.83 and $1.40 \mathrm{ard} / \mathrm{fed}$, respectively. The observed inconsistency in ranking and reduction in the mean square error under alpha lattice design suggested that Alpha Lattice design appears better to detect genotype differences than the RCBD and will therefore improve the efficiency of field trials. Kashif et al. (2011) on rice and Abd El-Shafi, (2014) on wheat reported that the ranks were not constant across the experiments.

Genotypes: Misr 1, 952/797/93, Giza 716 and X -1671 produced the highest seed yield recording 13.26, 12.31, 12.20 and 11.14 (ardab/fed), respectively in the first season. Meanwhile, in the second season, Genotype Giza 716 gave the highest seed yield (15.78 ard/fed) followed by, Misr 1, X -1671 and 952/797/93 recording (14.41, 12.99 and 11.94 ardab/fed), respectively. The differences between the ranks of the best genotypes through both seasons may be attributed to the effect of environmental factors and their interactions with genotypes. These results are in accordance with
Abdelkareem and Ahmed (2003), Hager (2012) and Abd El-Shafi (2014).

Based on the above, comparing means estimated from the RCBD and Alpha Lattice analyses indicates that genotypes ranking can differ amongst the two analyses. According to mean values obtained from a two-season experiments, differences in genotypes ranks between the RCBD and alpha lattice analyses present a challenge in selecting the best performing genotypes for a specific trait. The rank values of cultivars within experiments vary considerably from season to the other. Genotypes rankings were influenced by the degree of precision for individual faba bean genotype experiments.

Malak et al., (2003) calculated the broad sense heritability in alpha lattice analysis for many yield traits. Heritability in RCBD and alpha was concluded for yield (ard/fed). Results performed that alpha lattice heritability in both seasons (66.22 and $71.56 \%$, respectively) was better than the RCBD values (65.99 and $62.66 \%$, respectively). Therefore, Alpha Lattice analysis can increase the degree of precision, thence estimation of heritability. The results indicated a greater efficiency for alpha design, enabling more precise estimates of genotypic variance, greater precision in the prediction of heritability in the broad sense.

\section{Conclusion}

The results obtained from this study could be useful for plant breeders, statisticians and agronomists in order to increase the precision of field trials. According to the results obtained, it may be concluded that alpha lattice design provided smaller coefficients of variation and error mean squares as compared to RCBD presented more efficiency in comparing different genotypes. The use of alpha lattice design allows the adjustment of treatment means for block effects. Therefore this design should be employed while conducting field research trials the on faba bean and other crops when number of genotypes in the experiments is large. There is also a need to extend experimentation to more research stations for wider applicability of these designs for crops and for some other crops too. For plant breeding and selection trials alpha lattice design should be used in such a way that they form a resolvable incomplete block design. The alpha lattice design also provides effective control within replicate variability. The results presented here make a case of using Alpha Lattice design which enhances the chances of 
detecting varietal differences to a great extent. Results performed that broad sense heritability in alpha lattice design (66.22 and 71.56\%) was better than the RCBD values (65.99 and $62.66 \%$ ). both designs confirmed to Giza 716, Misr 1, X -1671 and 952/797/93 genotypes were the highest seed yield across two seasons. The results indicated a greater efficiency for Alpha design, enabling more precise estimates of genotypic variance, greater precision in the prediction of heritability in the broad sense.

\section{REFERENCES}

Abd El-Mohsen A. A. and Abo-Hegazy S. R. (2013). Comparing the relative efficiency of two experimental designs in wheat field trials. Sci. Res. Rev. J., 1(3): 101-109.

Abd El-Shafi M. A. (2014). Efficiency of classical complete and incomplete block designs in yield trial on bread wheat genotypes. Res. J. Agric. and Biol. Sci., 10(1): 17-23.

Abdelkareem A. A. and Ahmed K. Z. (2003). Somaclonal variation in bread wheat (Triticum aestivum L.). 2. Comparative field performance of somaclones and their original cultivars. Egypt. J. Plant Breed., 7:457-469.

Campbell B. T. and Bauer P. J. (2007). Improving the precision of cotton performance trials conducted on highly variable soils of the southeastern USA Coastal Plain. Plant Breed., 126: 622-627.

Costae Silva J., Dutkowski G.W. and Gilmour A. R. (2001). Analysis of early tree height in forest genetic trials is enhanced by including a spatially correlated residual Canad. J. Forest Res., 31: 1887-1893. (DOI:10.1139/cjfr-31-11-1887).

Cullis B.R. and Gleeson A. C. (1991). Spatial analysis of field experiments-an extension to two dimensions. Biometrics., 47: 14491460.

Fisher R. A. (1926). The arrangement of field experiments.J.Ministry Agric.,33:503-513.

Giesbrecht F. G. and Gumpertz M. L. (2004). Planning, Construction, and Statistical Analysis of Comparative Experiments. Wiley. New York, USA.

Gleeson A. C. and Cullis B. R. (1987). Residual maximum likelihood estimation of a neighbour model for field experiments. Biometrics, 43: 277-288.

Hager M. A. (2012). Using trend analysis models to improve efficiency of wheat
(Triticum aestivum L.) variety trials. Bull. Fac. Agric., Cairo Univ., 63: 252-260.

Hinkelman K. and Kempthorne O. (2006). Design and Analysis of Experiments. Vols. 1 and 2. Wiley., New York, USA.

Idrees N. and Khan M.I. (2009). Design improvement using uniformity trials experimental data. Pak. J. Agri. Sci., 46(4): 315-320.

Kashif M., Khanb M. I., Arifb M., Anwerc M. and Ijazc M. (2011). Efficiency of alpha lattice design in rice field trials in Pakistan. J. Sci. Res., 3 (1): 91-95.

Kempton R. A., Seraphin J. C. and Sword A. M. (1994). Statistical analysis of two dimensional variations in variety yield trials. J. Agric. Sci. Cambridge, 122: 335342.

Lentner M. and Bishop T. (1993). Experimental Design and Analysis (Second Ed.). Valley Book Company, Blacksburg, Virginia, USA.

Malak A.U. Khan F. M., Taimur M., Abid K. and Sayed J. A. (2013). Genetic divergence in F4:6 wheat lines for yield and its contributing traits. J. Plant Breed. Genet, 01 (03): 169-175.

Masood A.A., Mujahid Y., Khan M.I. and Abid S. (2006). Improving precision of agricultural field experiments. J. of Sust. Develop., 3(1,2): 11-13.

Masood M.A., Farooq K., Mujahid Y. and Anwar M.Z. (2008). Improvement in precision of agricultural field experiments through design and analysis. Pak. J. Life Soc. Sci., 6: 89-91.

Neter J., Khutner M., Nachtsheim C. and Wasserman W. (1996). Applied Linear Statistical Models. $4^{\text {th }}$ Ed. Irwin Series. Time Mirror. Education Group, pp: 111121.

Patterson H.D. and Williams E.R. (1976). A new class of resolvable incomplete block designs. Biometrika, 63: 83-90

Patterson H.D and Silvey V. (1980). Statutory and recommended list trials of crop varieties in the United Kingdom. J. Royal Stat. Soc., A 143: 219-252.

Patterson H. D. and Hunter E. A. (1983). The efficiency of incomplete block designs in national list and recommended list of cereal variety trials. J. Agric. Sci., Camb., 101(2): 427-433.

Payne R. W., Murray D. A., Harding S. A., Baird D.B. and Soutar D.M. (2011). An 
introduction to GenStat for windows $\left(14^{\text {th }}\right.$ Edition). VSN International, Hemel Hempstead, UK.

Sajjad M., Khan S.H. and Khan A. S. (2011). Exploitation of germplasm for grain yield improvement in spring wheat (Triticum aestivum L.). Int. J. Agric. Biol., 13(5): 695-700.

Sial M. A. (2007). Genetic heritability for grain yield and its related characters in spring wheat (Triticum aestivum L.). Pak. J. Bot. 39: 1503-1509.

Singh R.K. and Chaudhery B.D. (1985). Biometrical methods in quantitative genetic analysis. Kalyani Pub., N. Delhi, India.

Stroup W. W., Baenziger P. S. and Multize D. K. (1994). Removing spatial variation from :wheat yield trials: a comparison of methods. Crop Sci., 86: 62-66.
Yang R., Terrance Z. Y., Stanford S. B. and Manjula B. (2004). Efficiency of spatial analyses of field pea variety trials. Crop Sci., 44(1): 49-55.

Yau S. K. (1997). Efficiency of alpha-lattice designs in international variety yield trials of barley and wheat. J. Agric. Sci., Cambridge, 128: 5-9.

Yong-Bi F., Alvin D. Y. and Gene N. (2000). Incomplete block designs for genetic testing: Accuracy of ranking families and individuals. Forest Genetics, 7(4):287293.

Zarea-Fizabady A. and M. Ghodsi (2004). Evaluation of yield and yield components of facultative and winter bread wheat genotypes (Triticum aestivum L.) under different irrigation regimes in Khorasam Province in Iran. J. Agron., 3(3): 184-187.

\section{تقييم دقة التجارب الحقلية فى الفول البلدى \\ زينب السيد غريب ـ هلى السيد العربى ابراهيم ـ تامر سلامة المرصفاوى*}

المعمل المركزي لبحوث التصميم و التحليل الاحصائى و* قسم بحوث المحاصيل البقولية ـ معهد بحوث المحاصيل الحقلية

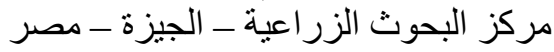

\section{ملخص بأنزم}

أجريت تجربتين حقليتين في محطة البحوث الزر اعية بالجيزة، مركز البحوث الزر اعية ، خلال موسمي 14/2013

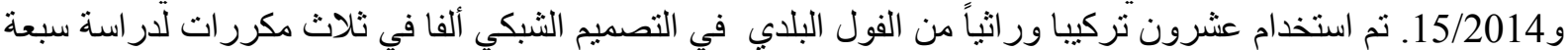

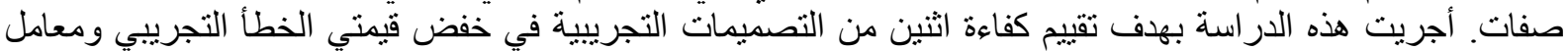

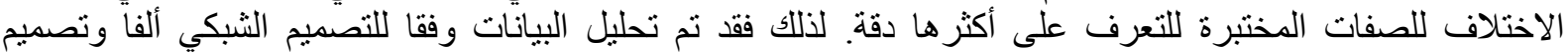

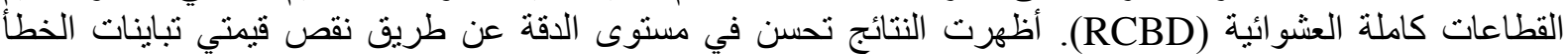
التجريبي ومعامل الاختلاف. وقد أظهرت نتائج الكفاءة النسبية (RE\%) للتجارب التهائ أن التصميم الثبكي ألفاً كان أكثر كفاءة

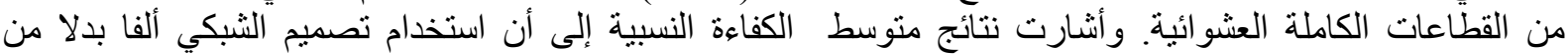

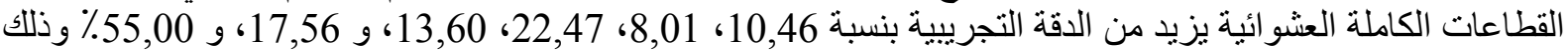

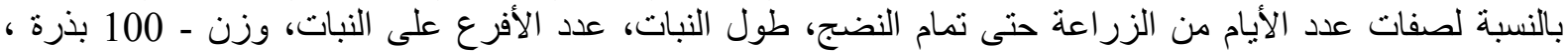

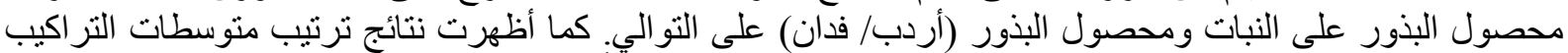

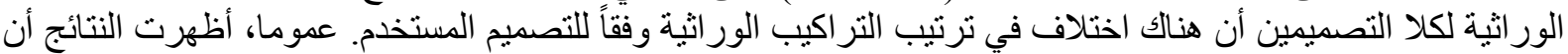

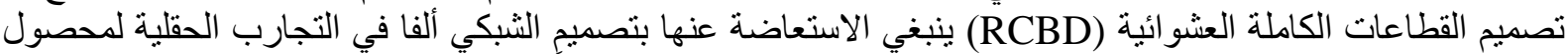

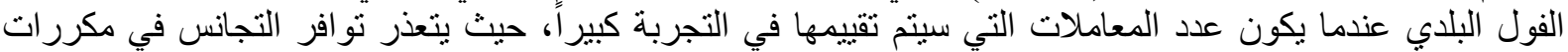

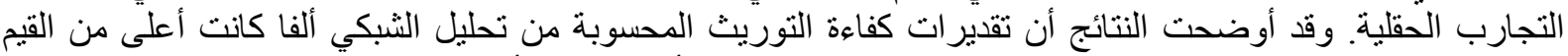

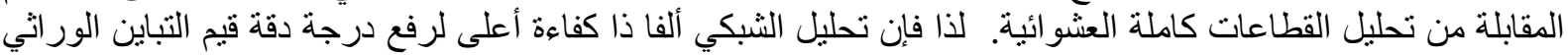
وبالتالي تقدير ات كفاءة التوريث باعل بالمعنى الو اسعح. 